\title{
Profitability of chemical protection and production costs in selected systems of sugar beet cultivation
}

\section{Opłacalność chemicznej ochrony oraz koszty produkcji w wybranych systemach uprawy buraka cukrowego}

\author{
Maria Golinowska ${ }^{1}$, Lesław Zimny ${ }^{2} *$
}

\section{Summary}

The research objective was to determine the costs of chemical plant protection, production and profitability of sugar beet production in five systems of conservation tillage. The study was conducted at the Experimental Station of University of Environmental and Life Sciences in Wrocław, in the years 2008-2010. Two factor experiment was established according to a split-plot method, in three replications. The investigation involved the costs of mulch coming from different crops, the costs of sugar beet cultivation for two levels of $\mathrm{N}$ fertilization: 80 and $120 \mathrm{~kg} / \mathrm{ha}$ as well as the costs of chemical plant protection. The highest economic efficiency of sugar beet production, in the form of the profit obtained (the highest bank deposit) was achieved from the system with pre-harvest straw, mixed by a cultivator and reduced nitrogen dose, as well as conservation tillage system with winter vetch. The expenses invested in the chemical plant protection ranged from 87.4 to $112.9 \mathrm{dt}$, which constituted 11.6 to $27.9 \%$ yield size. The system with white mustard provided the highest efficiency of protection treatments.

Key words: costs of cultivation; costs of plant protection; conservation tillage systems; sugar beet

\section{Streszczenie}

W latach 2008-2010 przeprowadzono badania w Rolniczym Zakładzie Doświadczalnym Swojec Uniwersytetu Przyrodniczego we Wrocławiu, których celem było określenie kosztów chemicznej ochrony oraz produkcji i opłacalności produkcji buraka cukrowego w pięciu różnych systemach uprawy konserwującej. W tym celu założono dwuczynnikowe doświadczenie metodą split-plot w trzech powtórzeniach. Badano koszty mulczu pochodzącego z różnych systemów uprawy oraz koszty uprawy buraka cukrowego dla dwóch poziomów nawożenia $\mathrm{N}$ : 80 i $120 \mathrm{~kg} /$ ha oraz koszty chemicznej ochrony. Najwyższą efektywność ekonomiczną produkcji buraka cukrowego w postaci uzyskanego dochodu (najwyższa lokata) - poza tradycyjnym systemem konserwującym z gorczycą - uzyskały systemy z obniżonymi dawkami azotu - ze słomą przedplonową wymieszaną kultywatorem oraz z wyką ozimą. Na chemiczną ochronę roślin należało przeznaczyć od 87,4 do 112,9 dt plonu, co stanowiło 11,6-27,9\% zbioru. Najwyższą efektywnością zabiegów ochronnych charakteryzował się system z gorczycą białą.

Słowa kluczowe: koszty uprawy; opłacalność chemicznej ochrony roślin; systemy uprawy konserwującej; burak cukrowy

\footnotetext{
Uniwersytet Przyrodniczy we Wrocławiu

pl. Grunwaldzki 24A, 50-363 Wrocław

${ }^{1}$ Instytut Nauk Ekonomicznych i Społecznych

${ }^{2}$ Katera Kształtowania Agroekosystemów i Terenów Zieleni

*corresponding author: leslaw.zimny@up.wroc.pl
} 


\section{Wstęp / Introduction}

Znaczenie gospodarcze uprawy buraka cukrowego wynika przede wszystkim z produkcji cukru dla potrzeb krajowych i eksportu. Jest to uprawa, która pozostawia po sobie dobre stanowisko dla roślin następczych. Obecnie plon uboczny jakim są liście zmienił przeznaczenie i stosowany jest jako nawóz zielony. Wprowadzenie do gleby plonu ubocznego buraka cukrowego pozwala na ograniczenie stosowania nawozów mineralnych (Wacławowicz 2013). Powierzchnia uprawy buraka cukrowego w Polsce w 2010 r. wynosiła około 200 tys. ha i wykazywała w latach 1989-2012 wyraźną tendencję spadkową (z ponad 400 tys. ha w 1989 r. do 212 tys. ha w 2012 r.) (Rocznik statystyczny). W tym okresie zmieniły się technologie uprawy buraka cukrowego. Transformacje organizacyjne i strukturalne spowodowały zmniejszenie się obsady inwentarza, a to przyczyniło się do obniżenia produkcji obornika i zaczęto wykorzystywać inne nawozy, takie jak międzyplony (Zimny i wsp. 2000, 2001; Strochalska 2011). Masa organiczna mulczu stała się bardzo ważnym elementem uprawy konserwującej i w porównaniu z uprawą tradycyjną, ma bezpośredni wpływ na obniżenie kosztów produkcji buraka cukrowego (Zimny 1999).

Celem badań było określenie opłacalności chemicznej ochrony roślin w uprawie buraka cukrowego dla pięciu systemów uprawy konserwującej w dwóch wariantach dawek azotu i kosztów uprawy w tych systemach.

\section{Materiały i metody / Materials and methods}

Badania przeprowadzono w Rolniczym Zakładzie Doświadczalnym Swojec we Wrocławiu w latach 20082010, które realizowano w oparciu o ściśłe, dwuczynnikowe doświadczenie polowe założone metodą split-plot w 3 powtórzeniach. Przed założeniem doświadczenia pole zwapnowano i zgłęboszowano. W doświadczeniu uwzględniono dwa czynniki (tab. 1). Czynnikiem I rzędu były zróżnicowane systemy uprawy konserwującej. Na obiekcie I (kontrola) stosowano tradycyjną uprawę konserwującą (międzyplon ścierniskowy - gorczyca pozostawiona do wiosny). Rozdrobnioną słomę przedplonową przykryto kultywatorem podorywkowym (obiekt II) lub po wymieszaniu broną zębową pozostawiono do wiosny $\mathrm{w}$ formie mulczu (obiekt III). Na pozostałych obiektach uprawiono żyto (obiekt IV) i wykę ozimą (obiekt V), które na wiosnę posłużyły jako mulcz. Na poletkach z mulczem ze słomy (obiekt II, III) i na poletkach z mulczem z międzyplonów ozimych (obiekt IV, V), wczesną wiosną, zastosowano Roundup 450 SL w celu zniszczenia międzyplonów i chwastów, a przed siewem agregat uprawowy złożony $\mathrm{z}$ brony wirnikowej i wału strunowego. Ponadto we wszystkich systemach wykonano nawożenie fosforowe, potasowe i dolistne. Czynnikiem II rzędu były dwa poziomy nawożenia azotowego: optymalne $-1 \mathrm{~N}(120 \mathrm{~kg} / \mathrm{ha})$, obniżone $2 / 3 \mathrm{~N}(80 \mathrm{~kg} / \mathrm{ha})$.

Tabela 1. Schemat doświadczenia

Table 1. Experimental design

\begin{tabular}{|c|c|c|c|}
\hline \multirow{2}{*}{ Czynnik - Factor } & \multirow{2}{*}{$\begin{array}{l}\text { Lp. } \\
\text { No. }\end{array}$} & \multicolumn{2}{|l|}{ Nazwa - Name } \\
\hline & & pełna - full & skrócona - simplified \\
\hline \multirow{5}{*}{$\begin{array}{l}\text { I czynnik: } \\
\text { Systemy uprawy } \\
\text { 1st order: } \\
\text { Conservation tillage } \\
\text { systems }\end{array}$} & 1 & $\begin{array}{l}\text { tradycyjna uprawa konserwująca z gorczycą białą pozosta- } \\
\text { wioną do wiosny - mulcz, agregat uprawowy, siew (kontrola) } \\
\text { traditional conservation tillage with white mustard left till } \\
\text { the spring - mulch, tillage set, sowing (control) }\end{array}$ & $\begin{array}{l}\text { gorczyca - mulcz } \\
\text { mustard - mulch }\end{array}$ \\
\hline & 2 & $\begin{array}{l}\text { słoma przedplonowa przykryta kultywatorem podorywkowym } \\
\text { i pozostawiona do wiosny - mulcz, Roundup } 450 \mathrm{SL} \text {, } \\
\text { agregat uprawowy, siew } \\
\text { forecrop straw covered with skimming cultivator and left till } \\
\text { the spring - mulch, Roundup } 450 \mathrm{SL} \text {, tillage set, sowing }\end{array}$ & $\begin{array}{l}\text { słoma przykryta + kultywator } \\
\text { straw + cultivator }\end{array}$ \\
\hline & 3 & $\begin{array}{l}\text { słoma przedplonowa wymieszana broną zębową } \\
\text { i pozostawiona do wiosny - mulcz, Roundup } 450 \mathrm{SL} \text {, } \\
\text { agregat uprawowy, siew } \\
\text { forecrop straw mixed with a tine harrow and left till the spring } \\
\text { - mulch, Roundup } 450 \mathrm{SL} \text {, tillage set, sowing }\end{array}$ & $\begin{array}{l}\text { słoma + brona } \\
\text { straw }+ \text { harrow }\end{array}$ \\
\hline & 4 & $\begin{array}{l}\text { uprawa żyta ozimego do wiosny - mulcz, Roundup } 450 \text { SL, } \\
\text { agregat uprawowy, siew } \\
\text { winter rye tillage left till the spring - mulch, Roundup } 450 \mathrm{SL} \text {, } \\
\text { tillage set, sowing }\end{array}$ & $\begin{array}{l}\text { żyto - mulcz } \\
\text { rye }- \text { mulch }\end{array}$ \\
\hline & 5 & $\begin{array}{l}\text { uprawa wyki ozimej do wiosny - mulcz, Roundup } 450 \text { SL, } \\
\text { agregat uprawowy, siew } \\
\text { winter vetch tillage left till the spring - mulch, Roundup } 450 \\
\text { SL, tillage set, sowing }\end{array}$ & $\begin{array}{l}\text { wyka ozima }- \text { mulcz } \\
\text { winter vetch }- \text { mulch }\end{array}$ \\
\hline \multirow{2}{*}{$\begin{array}{l}\text { II czynnik: } \\
\text { Nawożenie azotowe } \\
\text { 2nd order: } \\
\text { Nitrogen fertilization }\end{array}$} & 1 & optymalne $-120 \mathrm{~kg} / \mathrm{ha}-$ optimal $-120 \mathrm{~kg} / \mathrm{ha}$ & $1 \mathrm{~N}$ \\
\hline & 2 & obniżone $-80 \mathrm{~kg} / \mathrm{ha}$ - reduced - $80 \mathrm{~kg} / \mathrm{ha}$ & $2 / 3 \mathrm{~N}$ \\
\hline
\end{tabular}


Wszystkie zabiegi agrotechniczne, w tym siew, wykonywano tradycyjnymi narzędziami. Azot w postaci saletry wapniowej stosowano przedsiewnie $1 / 3$ dawki (40 i $26 \mathrm{~kg} / \mathrm{ha}$ ) oraz pogłównie 2/3 dawki (80 i $54 \mathrm{~kg} \mathrm{~N} / \mathrm{ha}$ ) najpóźniej do fazy 6. liścia. Nawożenie fosforowe i potasowe dostosowano do zasobności gleby - $60 \mathrm{~kg} \mathrm{P} / \mathrm{ha}$ i $80 \mathrm{~kg} \mathrm{~K} / \mathrm{ha}$. Burak cukrowy wysiewano w rozstawie
$0,18 \times 0,45 \mathrm{~m}$, zapewniającej optymalną obsadę roślin. Siew wykonano siewnikiem tradycyjnym (punktowym), możliwym do zastosowania $\mathrm{w}$ przeciętnym gospodarstwie rolniczym. Burak cukrowy pielęgnowano zgodnie z zaleceniami agrotechnicznymi i Kodeksem dobrych praktyk w produkcji buraków cukrowych (Bzowska-Bakalarz i Bieganowski 2008).

Tabela 2. Elementy technologii uprawy buraka cukrowego

Table 2. Elements of sugar beet cultivation technology

\begin{tabular}{|c|c|c|c|c|c|c|c|c|c|c|c|}
\hline \multirow{3}{*}{$\begin{array}{l}\text { Lp. } \\
\text { No. }\end{array}$} & \multirow{3}{*}{$\begin{array}{l}\text { Wyszczególnienie } \\
\text { Specification }\end{array}$} & \multicolumn{10}{|c|}{ Systemy - Systems } \\
\hline & & \multicolumn{2}{|c|}{$\begin{array}{l}\text { I gorczyca } \\
\text { I mustard }\end{array}$} & \multicolumn{2}{|c|}{$\begin{array}{l}\text { II słoma + } \\
\text { kultywator } \\
\text { II straw + } \\
\text { cultivator }\end{array}$} & \multicolumn{2}{|c|}{$\begin{array}{c}\text { III słoma }+ \\
\text { brona } \\
\text { III straw }+ \\
\text { harrow }\end{array}$} & \multicolumn{2}{|c|}{$\begin{array}{l}\text { IV żyto } \\
\text { IV rye }\end{array}$} & \multicolumn{2}{|c|}{$\begin{array}{l}\text { V wyka ozima } \\
\text { V winter vetch }\end{array}$} \\
\hline & & $1 \mathrm{~N}$ & $2 / 3 \mathrm{~N}$ & $1 \mathrm{~N}$ & $2 / 3 \mathrm{~N}$ & $1 \mathrm{~N}$ & $2 / 3 \mathrm{~N}$ & $1 \mathrm{~N}$ & $2 / 3 \mathrm{~N}$ & $1 \mathrm{~N}$ & $2 / 3 \mathrm{~N}$ \\
\hline 1 & $\begin{array}{l}\text { rozdrabnianie słomy } \\
\text { straw grinding }\end{array}$ & - & - & $\checkmark$ & $\checkmark$ & $\checkmark$ & $\checkmark$ & - & - & - & - \\
\hline 2 & $\begin{array}{l}\text { wapnowanie } \\
\text { liming }[4 \mathrm{t} / \mathrm{ha}]\end{array}$ & $\checkmark$ & $\checkmark$ & $\checkmark$ & $\checkmark$ & $\checkmark$ & $\checkmark$ & $\checkmark$ & $\checkmark$ & $\checkmark$ & $\checkmark$ \\
\hline 3 & $\begin{array}{l}\text { nawożenie } \\
\text { fertilization [N } 50 \mathrm{~kg} / \mathrm{ha}]\end{array}$ & - & - & $\checkmark$ & $\checkmark$ & $\checkmark$ & $\checkmark$ & - & - & - & - \\
\hline 4 & $\begin{array}{l}\text { głęboszowanie } \\
\text { subsoiling }\end{array}$ & $\checkmark$ & $\checkmark$ & $\checkmark$ & $\checkmark$ & $\checkmark$ & $\checkmark$ & $\checkmark$ & $\checkmark$ & $\checkmark$ & $\checkmark$ \\
\hline 5 & $\begin{array}{l}\text { podorywka + brona } \\
\text { skimming + harrow }\end{array}$ & $\checkmark$ & $\checkmark$ & - & - & - & - & $\checkmark$ & $\checkmark$ & $\checkmark$ & $\checkmark$ \\
\hline 6 & $\begin{array}{l}\text { bronowanie - brona ciężka } \\
\text { harrowing with a drag harrow }\end{array}$ & $\checkmark$ & $\checkmark$ & - & - & - & - & $\checkmark$ & $\checkmark$ & $\checkmark$ & $\checkmark$ \\
\hline 7 & Roundup 450 SL & - & - & $\checkmark$ & $\checkmark$ & $\checkmark$ & $\checkmark$ & $\checkmark$ & $\checkmark$ & $\checkmark$ & $\checkmark$ \\
\hline 8 & $\begin{array}{l}\text { uprawa agregatem } \\
\text { tillage with tillage set }\end{array}$ & - & - & - & - & - & - & $\checkmark$ & $\checkmark$ & $\checkmark$ & $\checkmark$ \\
\hline 9 & $\begin{array}{l}\text { wysiew nasion } \\
\text { seed sowing }[\mathrm{kg} / \mathrm{ha}]\end{array}$ & 20 & 20 & - & - & - & - & 160 & 160 & 90 & 90 \\
\hline 10 & $\begin{array}{l}\text { kultywator - podorywka } \\
\text { cultivator - skimming }\end{array}$ & - & - & $\checkmark$ & $\checkmark$ & - & - & - & - & - & - \\
\hline 11 & $\begin{array}{l}\text { brona zębowa } \\
\text { tine harrow }\end{array}$ & - & - & - & - & $\checkmark$ & $\checkmark$ & - & - & - & - \\
\hline 12 & $\begin{array}{l}\text { superfosfat } \\
\text { superphosphate }[\mathrm{kg} / \mathrm{ha}]\end{array}$ & 60 & 60 & 60 & 60 & 60 & 60 & 60 & 60 & 60 & 60 \\
\hline 13 & $\begin{array}{l}\text { sól potasowa } \\
\text { potassium salt }[\mathrm{kg} / \mathrm{ha}]\end{array}$ & 80 & 80 & 80 & 80 & 80 & 80 & 80 & 80 & 80 & 80 \\
\hline 14 & $\begin{array}{l}\text { siew buraka cukrowego } \\
\text { sugar beet sowing }\end{array}$ & $\checkmark$ & $\checkmark$ & $\checkmark$ & $\checkmark$ & $\checkmark$ & $\checkmark$ & $\checkmark$ & $\checkmark$ & $\checkmark$ & $\checkmark$ \\
\hline 15 & $\begin{array}{l}\text { zwalczanie chwastów } \\
\text { weed control }\end{array}$ & $\checkmark$ & $\checkmark$ & $\checkmark$ & $\checkmark$ & $\checkmark$ & $\checkmark$ & $\checkmark$ & $\checkmark$ & $\checkmark$ & $\checkmark$ \\
\hline 16 & $\begin{array}{l}\text { zwalczanie szkodników } \\
\text { pest control }\end{array}$ & $\checkmark$ & $\checkmark$ & $\checkmark$ & $\checkmark$ & $\checkmark$ & $\checkmark$ & $\checkmark$ & $\checkmark$ & $\checkmark$ & $\checkmark$ \\
\hline 17 & $\begin{array}{l}\text { zwalczanie chwościka } \\
\text { cercospora leaf spot control }\end{array}$ & $\checkmark$ & $\checkmark$ & $\checkmark$ & $\checkmark$ & $\checkmark$ & $\checkmark$ & $\checkmark$ & $\checkmark$ & $\checkmark$ & $\checkmark$ \\
\hline 18 & $\begin{array}{l}\text { dolistne dokarmianie } \\
\text { foliar feeding }\end{array}$ & $\checkmark$ & $\checkmark$ & $\checkmark$ & $\checkmark$ & $\checkmark$ & $\checkmark$ & $\checkmark$ & $\checkmark$ & $\checkmark$ & $\checkmark$ \\
\hline 19 & $\begin{array}{l}\text { nawożenie przedsiewne } \\
\text { pre-sowing fertilization }[\mathrm{kg} \mathrm{N} / \mathrm{ha}]\end{array}$ & 40 & 26 & 40 & 26 & 40 & 26 & 40 & 26 & 40 & 26 \\
\hline 20 & $\begin{array}{l}\text { nawożenie pogłówne } \\
\text { top dressing fertilization }[\mathrm{kg} \mathrm{N} / \mathrm{ha}]\end{array}$ & 80 & 54 & 80 & 54 & 80 & 54 & 80 & 54 & 80 & 54 \\
\hline 21 & $\begin{array}{l}\text { zbiór buraka cukrowego } \\
\text { sugar beet harvest }\end{array}$ & $\checkmark$ & $\checkmark$ & $\checkmark$ & $\checkmark$ & $\checkmark$ & $\checkmark$ & $\checkmark$ & $\checkmark$ & $\checkmark$ & $\checkmark$ \\
\hline
\end{tabular}


W tabeli 2. przedstawiono elementy technologii uprawy buraka cukrowego dla pięciu systemów. W kosztach uprawy buraka cukrowego uwzględniono następujące elementy:

- koszty mulczu, na które składają się w zależności od systemu: koszty siewu, rozdrabniania słomy, nawożenia saletrą wapniową,

- koszty użycia sprzętu, na podstawie czego oszacowano wartość mulczu przyjmując cenę $1 \mathrm{t}$ masy zielonej - 30 PLN i uwzględniając wykorzystanie 50\% masy organicznej w I roku,

- koszty bezpośrednie uprawy buraka cukrowego, które obejmowały: materiał siewny, nawożenie PK, nawożenie N, ochronę roślin, koszty uprawek, wapnowanie, dokarmianie dolistne oraz podatek gruntowy.

Koszty uprawek zostały określone na podstawie cen usług agrotechnicznych w oparciu o cennik usług mechanizacyjnych $\mathrm{z}$ elektronicznej platformy świadczenia usług (www.wodr.poznan.pl). W skład kosztów usług wchodziły: koszty pracy, koszty paliwa, koszty użycia maszyny (amortyzacja, remonty, ubezpieczenia) (Krzysiak 2009, 2011).

Analiza ekonomiczna różnych systemów uprawy konserwującej buraka cukrowego miała odpowiedzieć na pytanie, który system uprawy konserwującej osiągnął najwyższą efektywność produkcyjną i ekonomiczną. Metoda obliczania efektywności ekonomicznej polegała na zastosowaniu rachunku kalkulacji różnicowej (Ludwiczak 1989; Busłowski i Gędek 1997; Kucińska i wsp. 2004). Mulcz wyceniono metodą kosztów włożonych. Przychodami produkcji buraka cukrowego były: wartość korzeni, liści i wysłodków oraz dopłaty bezpośrednie, dopłata cukrowa i ryczałtowy zwrot podatku VAT. Przychody pomniejszone o koszty z uprawy stanowiły dochód z uprawy 1 ha.
Nakłady na chemiczną ochronę roślin w uprawie buraka cukrowego określono zgodnie $\mathrm{z}$ metodologią stosowaną w ekonomice ochrony roślin:

- zużycie pestycydów w uprawie wyrażono w masie kg s.cz. (substancja czynna) na 1 ha oraz wartościowo w PLN na 1 ha,

- strukturę zużycia pestycydów z podziałem na grupy pestycydów,

- krotność wykonywanych zabiegów,

- koszty faktyczne zabiegów ochrony roślin, składające się z kosztów środków ochrony roślin i kosztów ich zastosowania (Golinowska 1997),

- opłacalność chemicznych zabiegów ochrony roślin przedstawiono za pomocą orientacyjnych wskaźników opłacalności $E_{1}$ i $E_{2}$ :

$$
E_{1}=\frac{K_{z}}{C} \quad E_{2}=\frac{E_{1} \times 100}{p}
$$

$K_{z}-$ koszty zabiegu - treatments costs [PLN/ha],

$C$ - cena buraka cukrowego - sugar beet price [PLN/1 dt],

$p$ - plon buraka cukrowego w dt/ha - sugar beet yield [PLN/1 dt].

\section{Wyniki i dyskusja / Results and discussion}

W wyniku przeprowadzonych badań w latach 20082010 uzyskano plony korzeni i liści buraka cukrowego, które przedstawiono w tabeli 3. Średni plon korzeni z obu wariantów nawożenia azotem w przychodach stanowił od 60,8 do 72,0\% w zależności od rodzaju mulczu.

Tabela 3. Plony buraka cukrowego [t/ha]

Table 3. Sugar beet yields [t/ha]

\begin{tabular}{|c|c|c|c|c|c|c|c|c|c|c|c|c|}
\hline \multirow{2}{*}{$\begin{array}{l}\text { Systemy } \\
\text { Systems }\end{array}$} & \multicolumn{3}{|c|}{2008} & \multicolumn{3}{|c|}{2009} & \multicolumn{3}{|c|}{2010} & \multicolumn{3}{|c|}{ Średnio - Mean } \\
\hline & $1 \mathrm{~N}$ & $2 / 3 \mathrm{~N}$ & $\begin{array}{c}\text { średnio } \\
\text { mean }\end{array}$ & $1 \mathrm{~N}$ & $2 / 3 \mathrm{~N}$ & $\begin{array}{l}\text { średnio } \\
\text { mean }\end{array}$ & $1 \mathrm{~N}$ & $2 / 3 \mathrm{~N}$ & $\begin{array}{c}\text { średnio } \\
\text { mean }\end{array}$ & $1 \mathrm{~N}$ & $2 / 3 \mathrm{~N}$ & $\begin{array}{c}\text { średnio } \\
\text { mean }\end{array}$ \\
\hline \multicolumn{13}{|c|}{ Korzenie - Roots } \\
\hline I & 74,3 & 86,1 & 80,2 & 70,9 & 77,1 & 74,0 & 44,4 & 49,9 & 47,2 & 63,2 & 71,0 & 67,1 \\
\hline II & 56,7 & 87,3 & 72,0 & 69,4 & 67,4 & 68,4 & 38,1 & 54,7 & 46,4 & 54,7 & 69,8 & 62,3 \\
\hline III & 64,8 & 54,0 & 59,4 & 63,6 & 63,6 & 63,6 & 61,1 & 57,5 & 59,3 & 63,2 & 58,4 & 60,8 \\
\hline IV & 40,5 & 48,5 & 44,5 & 61,2 & 63,3 & 62,3 & 58,3 & 56,1 & 57,2 & 53,3 & 56,0 & 54,7 \\
\hline $\mathrm{V}$ & 76,2 & 71,2 & 73,7 & 98,2 & 88,6 & 93,4 & 47,9 & 49,9 & 48,9 & 74,1 & 69,9 & 72,0 \\
\hline $\begin{array}{l}\text { Średnio } \\
\text { Mean }\end{array}$ & 62,5 & 69,4 & - & 72,7 & 72,0 & - & 50,0 & 53,6 & - & 61,7 & 65,0 & - \\
\hline \multicolumn{13}{|c|}{ Liście-Leaves } \\
\hline I & 45,4 & 45,4 & 45,4 & 37,2 & 46,8 & 42,0 & 52,0 & 39,8 & 45,9 & 44,9 & 44,0 & 44,5 \\
\hline II & 42,8 & 49,3 & 46,1 & 37,9 & 37,1 & 37,5 & 40,9 & 46,2 & 43,6 & 40,6 & 44,2 & 42,4 \\
\hline III & 30,1 & 28,5 & 29,3 & 35,1 & 39,3 & 37,2 & 45,1 & 50,9 & 48,0 & 36,8 & 39,6 & 38,2 \\
\hline IV & 35,3 & 28,2 & 31,8 & 37,5 & 39,5 & 38,5 & 42,4 & 39,9 & 41,2 & 38,4 & 35,9 & 37,2 \\
\hline $\mathrm{V}$ & 39,3 & 39,6 & 39,5 & 54,2 & 48,3 & 51,3 & 45,0 & 41,6 & 43,3 & 46,2 & 43,2 & 44,7 \\
\hline $\begin{array}{l}\text { Średnio } \\
\text { Mean }\end{array}$ & 38,6 & 38,2 & - & 40,4 & 42,2 & - & 45,1 & 43,7 & - & 41,4 & 41,4 & - \\
\hline
\end{tabular}

Źródło: obliczenia własne - Source: own calculations 
Tabela 4. Średnie przychody z uprawy 1 ha buraka cukrowego [PLN/ha]. Średnie z lat 2008-2010

Table 4. Production value and income [PLN/ha]. Mean for 2008-2010

\begin{tabular}{|c|c|c|c|c|c|c|c|c|c|c|c|}
\hline \multirow{3}{*}{$\begin{array}{l}\text { Lp. } \\
\text { No. }\end{array}$} & \multirow{3}{*}{$\begin{array}{l}\text { Wyszczególnienie } \\
\text { Specification }\end{array}$} & \multicolumn{10}{|c|}{ Systemy - Systems } \\
\hline & & \multicolumn{2}{|c|}{$\begin{array}{l}\text { I gorczyca } \\
\text { I mustard }\end{array}$} & \multicolumn{2}{|c|}{$\begin{array}{l}\text { II słoma }+ \\
\text { kultywator } \\
\text { II straw }+ \\
\text { cultivator }\end{array}$} & \multicolumn{2}{|c|}{$\begin{array}{l}\text { III słoma } \\
\text { + brona } \\
\text { III straw } \\
\text { + harrow }\end{array}$} & \multicolumn{2}{|c|}{$\begin{array}{l}\text { IV żyto } \\
\text { IV rye }\end{array}$} & \multicolumn{2}{|c|}{$\begin{array}{l}\text { V wyka ozima } \\
\text { V winter vetch }\end{array}$} \\
\hline & & $1 \mathrm{~N}$ & $2 / 3 \mathrm{~N}$ & $1 \mathrm{~N}$ & $2 / 3 \mathrm{~N}$ & $1 \mathrm{~N}$ & $2 / 3 \mathrm{~N}$ & $1 \mathrm{~N}$ & $2 / 3 \mathrm{~N}$ & $1 \mathrm{~N}$ & $2 / 3 \mathrm{~N}$ \\
\hline 1 & korzenie - roots & 7285 & 8178 & 6338 & 8057 & 7414 & 6880 & 6368 & 6616 & 8562 & 8107 \\
\hline 2 & liście - leaves & 1346 & 1320 & 1216 & 1340 & 1103 & 1185 & 1152 & 1076 & 1385 & 1295 \\
\hline 3 & wysłodki - beet pulp & 323 & 323 & 323 & 323 & 323 & 323 & 323 & 323 & 323 & 323 \\
\hline 4 & $\begin{array}{l}\text { dopłaty bezpośrednie } \\
\text { direct payment }\end{array}$ & 382 & 382 & 382 & 382 & 382 & 382 & 382 & 382 & 382 & 382 \\
\hline 5 & $\begin{array}{l}\text { dopłata cukrowa } \\
\text { sugar subsidy }\end{array}$ & 1811 & 1909 & 1699 & 1995 & 2110 & 2047 & 2059 & 2022 & 1875 & 1909 \\
\hline 6 & $\begin{array}{l}\text { ryczałtowy zwrot VAT } \\
\text { flat - rate refund of VAT }\end{array}$ & 222 & 222 & 222 & 222 & 222 & 222 & 222 & 222 & 222 & 222 \\
\hline 7 & $\begin{array}{l}\text { razem przychody } \\
\text { total income }\end{array}$ & 11369 & 12335 & 10180 & 12619 & 11556 & 11039 & 10507 & 10641 & 12753 & 12238 \\
\hline 8 & $\begin{array}{l}\text { udział dopłat } \\
\text { w przychodach } \\
\text { share of subsidies } \\
\text { in income [\%] }\end{array}$ & 19,3 & 18,6 & 20,4 & 18,8 & 21,6 & 22,0 & 23,1 & 22,6 & 17,7 & 18,7 \\
\hline 9 & $\begin{array}{l}\text { dochód }(\mathrm{P}-\mathrm{K}) \\
\text { income }(\mathrm{P}-\mathrm{K})\end{array}$ & 2638 & 3903 & 3372 & 6111 & 5023 & 4808 & 3082 & 3517 & 5258 & 5044 \\
\hline 10 & $\begin{array}{l}\text { dochód bez dopłat } \\
\text { income without subsidies }\end{array}$ & 445 & 1612 & 1291 & 3734 & 2531 & 2379 & 1361 & 1113 & 3001 & 2753 \\
\hline 11 & $\begin{array}{l}\text { lokata dochodu } \\
\text { income investment }\end{array}$ & 10 & 6 & 8 & 1 & 4 & 5 & 9 & 7 & 2 & 3 \\
\hline 12 & $\begin{array}{l}\text { lokata dochodu } \\
\text { bez dopłat } \\
\text { income investment } \\
\text { without subsidies }\end{array}$ & 10 & 6 & 8 & 1 & 4 & 5 & 7 & 9 & 2 & 3 \\
\hline
\end{tabular}

Źródło: obliczenia własne - Source: own calculations

Przychody z uprawy 1 ha buraka cukrowego w latach 2008-2010 przedstawiono w tabeli 4. Zróżnicowanie tych przychodów waha się od 10180 do 12753 PLN/ha.

Na szczególną uwagę w przychodach zasługuje dopłata cukrowa, której udział średnio za trzy lata wynosił od 14,7 do $19,6 \%$ przychodów (tab. 4).

Koszty uprawy 1 ha buraka cukrowego przedstawiono w tabeli 5. W kalkulacji tych kosztów uwzględniono koszty mulczu oraz koszty bezpośrednie. Udział kosztów mulczu wynosił od 20,8 do $41,8 \%$ kosztów uprawy. W kosztach bezpośrednich wysoki udział miały koszty nawożenia NPK i koszty ochrony roślin. Udział kosztów ochrony roślin (kosztów faktycznych) w kosztach uprawy, w zależności od systemu uprawy, wynosił od 10,7 do $18,8 \%$. Udział kosztów faktycznych ochrony roślin w kosztach bezpośrednich, w każdym systemie uprawy konserwującej przekraczał $20 \mathrm{PLN} /$ ha. Wysoki udział kosztów ochrony roślin w kosztach uprawy winien być dla producenta potwierdzeniem słuszności podjętych decyzji dotyczących opłacalności tegoż zabiegu.

$Z$ rysunków 1. i 2., obrazujących elementy technologii uprawy buraka cukrowego wynika, że w pierwszym systemie każdego roku, dla dwóch wariantów nawożenia azotem wykonywano 5 zabiegów ochronnych, a w pozostałych systemach po 6 zabiegów, w tym cztery zabiegi wykonywano redukując stan zachwaszczenia oraz po jednym zabiegu przeciwko szkodnikom i chorobom grzybowym. Na 1 ha uprawy zużyto $2,81 \mathrm{~kg}$ s.cz. na 1 ha dla systemów II-V, a dla I systemu z gorczycą $1,73 \mathrm{~kg}$ s.cz. na 1 ha. W strukturze zużycia pestycydów zarówno w s.cz., jak i w PLN, udział herbicydów przy pełnym i obniżonym nawożeniu azotem był znaczny i wahał się od 63,0 do $77,0 \%$ s.cz. i od 66,0 do $69,0 \%$ w PLN.

Średni koszt [PLN/ha] jednorazowego zabiegu ochronnego w latach w zależności od krotności zabiegów wynosił:

\begin{tabular}{c|c|c}
\hline \multirow{2}{*}{$\begin{array}{c}\text { Rok } \\
\text { Year }\end{array}$} & \multicolumn{2}{|c}{ Zużycie pestycydów - Use of pesticides } \\
\cline { 2 - 3 } & $\begin{array}{c}\text { A } \\
\text { zabiegów ochronnych } \\
5 \text { treatment } \\
(1,73 \mathrm{~kg} \mathrm{s.cz} . / \mathrm{ha})\end{array}$ & $\begin{array}{c}\mathrm{B} \\
6 \text { zabiegów ochronnych } \\
\text { 6 treatment } \\
(2,81 \mathrm{~kg} \mathrm{s.cz} . / \mathrm{ha})\end{array}$ \\
\hline 2008 & 208 & 196 \\
2009 & 226 & 210 \\
2010 & 240 & 227 \\
\hline
\end{tabular}


Tabela 5. Struktura kosztów uprawy buraka cukrowego

Table 5. Structure of sugar beet costs production

\begin{tabular}{|c|c|c|c|c|c|c|c|c|c|c|c|}
\hline \multirow{3}{*}{$\begin{array}{l}\text { Lp. } \\
\text { No. }\end{array}$} & \multirow{3}{*}{$\begin{array}{l}\text { Wyszczególnienie } \\
\text { Specification }\end{array}$} & \multicolumn{10}{|c|}{ Systemy - Systems } \\
\hline & & \multicolumn{2}{|c|}{$\begin{array}{l}\text { I gorczyca } \\
\text { I mustard }\end{array}$} & \multicolumn{2}{|c|}{$\begin{array}{l}\text { II słoma }+ \\
\text { kultywator } \\
\text { II straw }+ \\
\text { cultivator }\end{array}$} & \multicolumn{2}{|c|}{$\begin{array}{l}\text { III słoma + brona } \\
\text { III straw + harrow }\end{array}$} & \multicolumn{2}{|c|}{$\begin{array}{l}\text { IV żyto } \\
\text { IV rye }\end{array}$} & \multicolumn{2}{|c|}{$\begin{array}{l}\mathrm{V} \text { wyka ozima } \\
\mathrm{V} \text { winter vetch }\end{array}$} \\
\hline & & $1 \mathrm{~N}$ & $2 / 3 \mathrm{~N}$ & $1 \mathrm{~N}$ & $2 / 3 \mathrm{~N}$ & $1 \mathrm{~N}$ & $2 / 3 \mathrm{~N}$ & $1 \mathrm{~N}$ & $2 / 3 \mathrm{~N}$ & $1 \mathrm{~N}$ & $2 / 3 \mathrm{~N}$ \\
\hline 1 & $\begin{array}{l}\text { Koszty uprawy } 1 \text { ha } \\
\text { Costs production } 1 \text { ha } \\
{[\text { PLN/ha] }}\end{array}$ & 8731 & 8431 & 6808 & 6508 & 6531 & 6231 & 7424 & 7124 & 7494 & 7194 \\
\hline 2 & $\begin{array}{l}\text { Koszty mulczu } \\
\text { Mulch costs }[\%]\end{array}$ & 41,3 & 41,8 & 20,8 & 21,8 & 21,7 & 22,7 & 28,8 & 29,9 & 28,5 & 29,7 \\
\hline 3 & $\begin{array}{l}\text { Koszty bezpośrednie } \\
\text { Direct costs [\%] } \\
\text { w tym: - including: } \\
\text { - koszty nawożenia } \\
\text { fertilization costs } \\
\text { - koszty ochrony roślin } \\
\text { plant protection costs }\end{array}$ & $\begin{array}{l}58,7 \\
18,8 \\
10,7\end{array}$ & $\begin{array}{l}15,9 \\
12,3\end{array}$ & $\begin{array}{l}24,2 \\
17,3\end{array}$ & $\begin{array}{l}20,6 \\
18,6\end{array}$ & $\begin{array}{l}25,1 \\
18,0\end{array}$ & $\begin{array}{l}21,5 \\
18,8\end{array}$ & $\begin{array}{l}22,1 \\
15,8\end{array}$ & $\begin{array}{l}18,8 \\
16,5 \\
\end{array}$ & $\begin{array}{l}21,9 \\
15,7\end{array}$ & $\begin{array}{l}18,6 \\
16,3\end{array}$ \\
\hline 4 & $\begin{array}{l}\text { Koszty bezpośrednie } \\
\text { Direct costs [PLN/ha] } \\
\text { w tym: - including: } \\
\text { - koszty nawożenia } \\
\text { costs of fertilization } \\
\text { [PLN/ha] } \\
\text { - koszty ochrony roślin } \\
\text { costs of plant protection } \\
\text { [PLN/ha] }\end{array}$ & 5127 & 4827 & 30,4 & 5091 & 5114 & 4814 & 31,0 & 26,9 & 30,6 & 5061 \\
\hline
\end{tabular}

Źródło: badania własne - Source: according to own research

Tabela 6. Orientacyjne wskaźniki opłacalności chemicznej ochrony buraka cukrowego

Table 6. Profitability index of chemical plant protection of sugar beet

\begin{tabular}{|c|c|c|c|c|c|c|c|c|c|c|c|c|}
\hline \multirow{3}{*}{$\begin{array}{l}\text { Lp. } \\
\text { No. }\end{array}$} & \multirow{3}{*}{$\begin{array}{l}\text { Rok } \\
\text { Year }\end{array}$} & \multirow{3}{*}{$\begin{array}{l}\text { Wskaźnik } \\
\text { Index }\end{array}$} & \multicolumn{10}{|c|}{ Systemy - Systems } \\
\hline & & & \multicolumn{2}{|c|}{$\begin{array}{l}\text { I gorczyca } \\
\text { I mustard }\end{array}$} & \multicolumn{2}{|c|}{$\begin{array}{l}\text { II słoma + } \\
\text { kultywator } \\
\text { II straw }+ \\
\text { cultivator }\end{array}$} & \multicolumn{2}{|c|}{$\begin{array}{l}\text { III słoma }+ \text { brona } \\
\text { III straw }+ \text { harrow }\end{array}$} & \multicolumn{2}{|c|}{$\begin{array}{l}\text { IV żyto } \\
\text { IV rye }\end{array}$} & \multicolumn{2}{|c|}{$\begin{array}{l}\text { V wyka ozima } \\
\text { V winter vetch }\end{array}$} \\
\hline & & & $1 \mathrm{~N}$ & $2 / 3 \mathrm{~N}$ & $1 \mathrm{~N}$ & $2 / 3 \mathrm{~N}$ & $1 \mathrm{~N}$ & $2 / 3 \mathrm{~N}$ & $1 \mathrm{~N}$ & $2 / 3 \mathrm{~N}$ & $1 \mathrm{~N}$ & $2 / 3 \mathrm{~N}$ \\
\hline 1 & \multirow{2}{*}{2008} & $E_{1}$ & 100,0 & 100,0 & 112,9 & 112,9 & 112,9 & 112,9 & 112,9 & 112,9 & 112,9 & 112,9 \\
\hline 2 & & $E_{2}$ & 13,5 & 11,6 & 19,9 & 12,9 & 17,4 & 20,9 & 27,9 & 23,3 & 14,8 & 15,9 \\
\hline 3 & \multirow{2}{*}{2009} & $E_{1}$ & 97,4 & 87,4 & 108,5 & 108,5 & 108,5 & 108,5 & 108,5 & 108,5 & 108,5 & 108,5 \\
\hline 4 & & $E_{2}$ & 13,7 & 12,6 & 16,1 & 15,9 & 17,1 & 17,1 & 17,1 & 17,4 & 12,3 & 11,6 \\
\hline 5 & \multirow{2}{*}{2010} & $E_{1}$ & 90,2 & 90,2 & 102,2 & 102,3 & 102,3 & 102,3 & 102,3 & 102,3 & 102,3 & 102,5 \\
\hline 6 & & $E_{2}$ & 20,2 & 18,1 & 26,9 & 18,7 & 16,7 & 17,8 & 17,6 & 18,2 & 25,7 & 20,5 \\
\hline 7 & \multirow{2}{*}{$\begin{array}{c}\text { średnio } \\
\text { mean }\end{array}$} & $E_{1}$ & 95,9 & 92,5 & 107,9 & 107,9 & 107,9 & 107,9 & 107,9 & 107,9 & 107,9 & 108,0 \\
\hline 8 & & $E_{2}$ & 15,8 & 14,1 & 21,0 & 15,8 & 17,1 & 18,6 & 20,9 & 19,6 & 17,6 & 16,0 \\
\hline
\end{tabular}

Źródło: badania własne według wzorów:

$$
E_{1}=\frac{\text { Koszty faktyczne } \times \text { Plon }}{\text { Cena produktu chronionego }}, \quad E_{2}=\frac{E_{1}}{\text { Plon }}
$$

Source: according to own research:

$$
E_{1}=\frac{\text { Costs explicite } \mathrm{x} \text { Yield }}{\text { Prices of } 1 \mathrm{dt} \text { yield }}, \quad E_{2}=\frac{E_{1}}{\text { Yield }}
$$




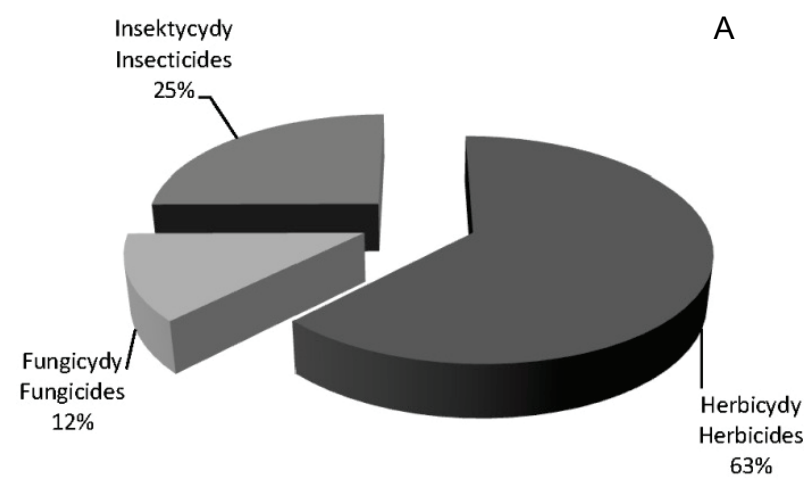

A - 5 zabiegów ochronnych -5 treatment $(1,73 \mathrm{~kg} \mathrm{s.cz./ha)}$ B -6 zabiegów ochronnych -6 treatment $(2,81 \mathrm{~kg} \mathrm{s.cz./ha})$

Rys. 1. Struktura zużycia pestycydów w kg substancji czynnej

Fig. 1. Use structure pesticides in $\mathrm{kg}$ active substance

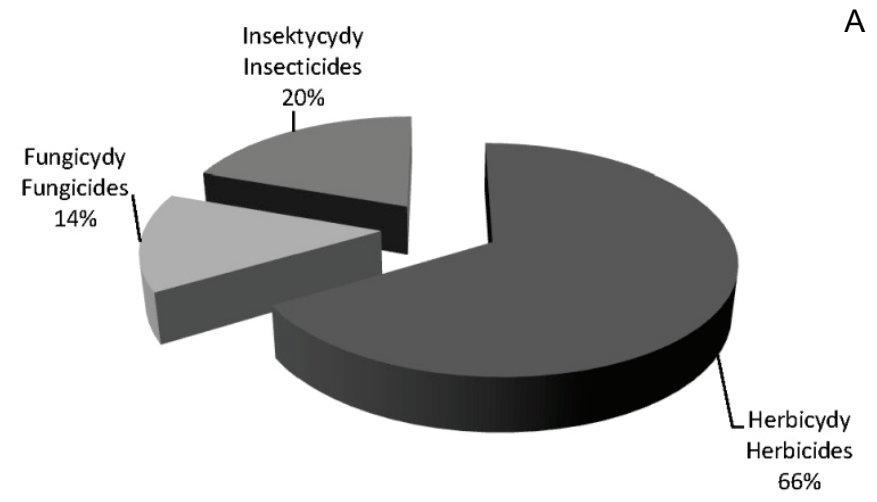

A

A -5 zabiegów ochronnych -5 treatment $(1,73 \mathrm{~kg} \mathrm{s.cz} / \mathrm{ha})$ B - 6 zabiegów ochronnych -6 treatment $(2,81 \mathrm{~kg} \mathrm{s.cz./ha)}$

Rys. 2. Struktura zużycia pestycydów w PLN

Fig. 2. Structure use of pesticides in PLN

Opłacalność przeprowadzania zabiegów ochrony roślin została przedstawiona za pomocą orientacyjnego wskaźnika opłacalności $w$ dwóch formach: $w \mathrm{dt} / \mathrm{ha}\left(\mathrm{E}_{1}\right)$ oraz w \% plonu pokrywającego koszty zabiegu ( $\left.E_{2}\right)$ (tab. 6).

W pierwszym roku badań na pokrycie kosztów faktycznych zabiegów ochronnych należało przeznaczyć od 100 do 112,9 dt i stanowiło to od 11,6 do $27,9 \%$ zbioru. W tym roku najwyższą opłacalnością charakteryzował się system I, a najgorszą system IV. W roku następnym najlepszą opłacalnością charakteryzował się system V i I, a w roku 2010 system III wykazał najlepsze wyniki. Na kształtowanie się tych wskaźników decydujący wpływ miał uzyskany plon. Wyższe wskaźniki opłacalności chemicznej ochrony roślin uzyskano w wariantach o zmniejszonym nawożeniu N (2/3) oraz w systemie uprawy konserwującej I (gorczyca).

\section{Wnioski / Conclusions}

1. Średnie za trzy lata koszty uprawy buraka cukrowego w zależności od systemu uprawy konserwującej wahały się od 6231 do 8731 PLN/ha. Najniższe koszty uprawy 1 ha uzyskano w systemie ze słomą przykrytą broną
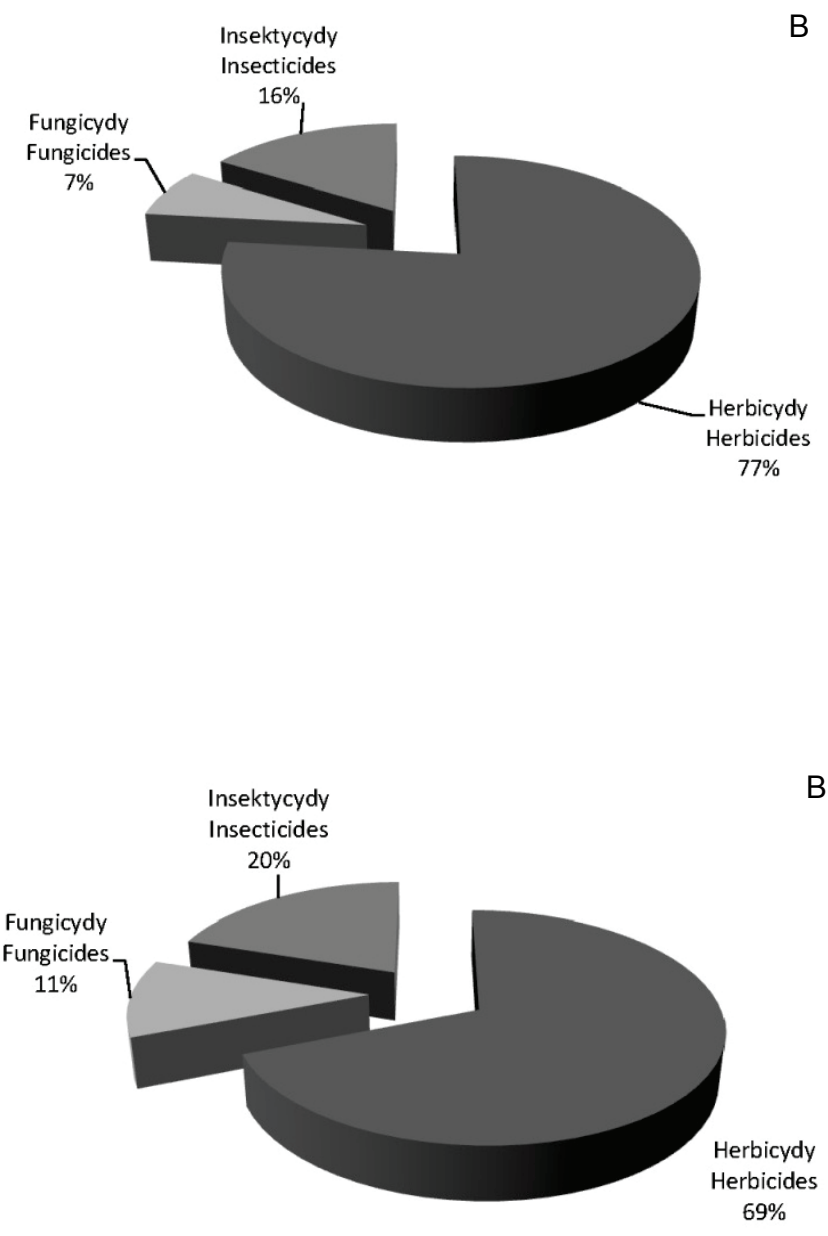

W wariancie $\mathrm{z}$ obniżoną dawką azotu, a najwyższe $\mathrm{W}$ systemie $\mathrm{z}$ gorczycą pozostawioną do wiosny w postaci mulczu $\mathrm{w}$ wariancie $\mathrm{z}$ pełną dawką azotu.

2. Udział kosztów mulczu w kosztach uprawy w systemie $\mathrm{z}$ gorczycą stanowił ponad $41 \%$ i był on w porównaniu do wariantu ze słomą przykrytą broną o $187,2 \%$ wyższy.

3. Udział kosztów ochrony roślin w kosztach uprawy buraka cukrowego wahał się od 10,7 do $18,8 \%$, a w kosztach bezpośrednich od 20,3 do 24,4 PLN/ha.

4. W procesie produkcji buraka cukrowego zużyto 1,73 (5 zabiegów) lub 2,81 (6 zabiegów) $\mathrm{kg}$ s.cz./ha. W strukturze zużycia pestycydów redukowanie stanu zachwaszczenia $\mathrm{w}$ systemie $\mathrm{z}$ gorczycą stanowiło $66,4 \%$, a w pozostałych wariantach $69 \%$.

5. Na pokrycie kosztów faktycznych ochrony roślin w zależności od roku systemu i wariantu nawożenia azotem należało przeznaczyć od 11,6 do $27,9 \%$ zbioru. Najkorzystniejsze wskaźniki opłacalności ochrony roślin wykazał system z gorczycą przy obniżonej i pełnej dawce azotu oraz ze słomą przykrytą kultywatorem przy obniżonym nawożeniu azotowym. Na kształtowanie się tego wskaźnika duży wpływ miał uzyskiwany plon. 


\section{Literatura / References}

Busłowski A., Gędek S. 1997. Kalkulacje różnicowe - ankieta przydatności do podejmowania decyzji. Studia Ekonomiczne 4: 5-16.

Bzowska-Bakalarz M., Bieganowski A. (red.). 2008. Kodeks dobrych praktyk w produkcji buraków cukrowych. Wyd. Instytutu Agrofizyki im. Bohdana Dobrzańsiego PAN, Lublin, 46 ss.

Golinowska M. 1997. Ekonomiczna efektywność chemicznej ochrony buraka cukrowego w gospodarstwach drobnotowarowych położonych w strefie ochrony sanitarnej zbiornika wodnego „Otmuchów”. Biuletyn Instytutu Hodowli i Aklimatyzacji Roślin 202: 295-302.

Golinowska M. 2002. Efektywność ochrony roślin w indywidualnych gospodarstwach rolnych południowo-zachodniej Polski. Zeszyty Naukowe Akademii Rolniczej we Wrocławiu 433, 199 ss.

Krzysiak Z. 2009. Koszty i opłacalność produkcji buraków cukrowych w roku 2007. Zagadnienia Ekonomiki Rolnej 3: $133-139$.

Krzysiak Z. 2011. Opłacalność produkcji buraków cukrowych w warunkach reformy rynku cukru. Zeszyty Naukowe Szkoły Głównej Gospodarstwa Wiejskiego, Ekonomika i Organizacja Gospodarki Żywnościowej 87: 119-126.

Kucińska K., Artyszak A., Ostrowska D. 2004. Efektywność nawożenia buraka cukrowego (Beta vulgaris altissima Döll.) różnymi nawozami organicznymi przy wzrastających dawkach azotu mineralnego. Biuletyn Instytutu Hodowli i Aklimatyzacji Roślin 234: $165-170$.

Ludwiczak J. 1989. Rachunkowość rolnicza. Skrypt Akademii Rolniczej we Wrocławiu 345, 120 ss.

Rocznik statystyczny rolnictwa. GUS, Warszawa.

Strochalska B. 2011. Produkcja buraka cukrowego w różnych systemach uprawy konserwującej. Praca doktorska. Uniwersytet Przyrodniczy we Wrocławiu, 76 ss.

Wacławowicz R. 2013. Siedliskowe i produkcyjne skutki polowego zagospodarowania liści buraka cukrowego. Wydawnictwo Uniwersytetu Przyrodniczego we Wrocławiu, 134 ss.

www.wodr.poznan.pl [dostęp: 19.05.2015].

Zimny L. 1997. Koszty produkcji buraka cukrowego w warunkach zróżnicowanych technologii uprawy. Konferencja „Progress in sugar beet cultivation and root quality”. Szkoła Główna Gospodarstwa Wiejskiego. Warszawa, 4-5.09.1997: 96-98.

Zimny L. 1999. Uprawa konserwująca buraka cukrowego. Postępy Nauk Rolniczych 5: 41-52.

Zimny L., Malak D., Śniady R. 2000. Znaczenie produkcyjne gorczycy białej i nawożenia azotowego w uprawie buraka cukrowego. Zeszyty Problemowe Postępów Nauk Rolniczych 470: 181-189.

Zimny L., Śniady R., Krzyśków S. 2001. Efektywność ekonomiczna uprawy buraka cukrowego w warunkach zróżnicowanego nawożenia organicznego i wzrastających dawkach azotu mineralnego. Zeszyty Naukowe Akademii Rolniczej we Wrocławiu, Rolnictwo 80: 189-195. 